\title{
Sistem Informasi Geografis Lokasi Lembaga Pendidikan Berbasis Islam (RA s.d. Pesantren) di Kabupaten Cilacap
}

\author{
Isti Qomariyah Kumala Dewi ${ }^{[1]}$, Kodrat Iman Satoto ${ }^{[2]}$, Ike Pertiwi Windasari ${ }^{[2]}$ \\ Program Studi Sistem Komputer, Fakultas Teknik, Universitas Diponegoro \\ istiqkdewi@gmail.com
}

\begin{abstract}
Abstrak - Lembaga pendidikan berbasis Islam di Kabupaten Cilacap berjumlah cukup banyak dan tersebar di seluruh wilayah Kabupaten Cilacap. Namun, informasi tentang lembaga pendidikan berbasis Islam di Kabupaten Cilacap masih sedikit diketahui oleh masyarakat. Salah satu faktor yang menyebabkan hal ini adalah ketersediaan data yang sedikit dan tidak lengkap, sedangkan kebutuhan informasi masyarakat cukup tinggi. Oleh karena itu, sistem informasi geografis ini dirancang dan dibangun untuk menyediakan informasi lokasi dan profil tentang lembaga pendidikan berbasis Islam yang ada di Kabupaten Cilacap secara lebih lengkap.

Perancangan dan pembangunan sistem informasi geografis pada penelitian ini menggunakan model proses waterfall. Analisis kebutuhan dilakukan dengan cara observasi dan membaca dokumen hasil survai. Perancangan sistem dibuat dengan mendefinisikan spesifikasi teknis dan pemodelan dengan ERD, DFD, dan Kamus Data. Sistem informasi geografis dibangun berbasis web dengan menggunakan bahasa pemrograman PHP, basis data MySQL, dan basis peta Google Maps API. Pengujian perangkat lunak dilakukan menggunakan metode black-box.

Hasil yang diperoleh dari penelitian ini adalah SIG sekolah Islam dapat menampilkan peta penunjuk lokasi dan data sekolah Islam untuk pengguna dengan cepat dan praktis jika dibandingkan dengan pencarian melalui peta konvensional dan pencarian manual melalui mesin pencari di internet. SIG sekolah Islam dapat dijangkau dengan mudah karena berbasis situs web. Data sekolah dalam SIG sekolah Islam dapat diperbarui sewaktu-waktu dengan mudah karena aplikasi ini mempunyai halaman admin. Aplikasi SIG sekolah Islam dapat menjadi salah satu rekomendasi dan alternatif solusi penyedia informasi tentang sekolah Islam di Kabupaten Cilacap.
\end{abstract}

Kata-kunci - sistem informasi geografis, sekolah Islam, web, Kabupaten Cilacap

\section{PENDAHULUAN}

\section{A. Latar Belakang}

Pendidikan adalah usaha sadar dan terencana untuk mewujudkan suasana belajar dan proses pembelajaran agar peserta didik secara aktif mengembangkan potensi dirinya untuk memiliki kekuatan spiritual keagamaan, pengendalian diri, kepribadian, kecerdasan, akhlak mulia, serta keterampilan yang diperlukan dirinya, masyarakat, bangsa dan negara (Republik Indonesia, 2003).

Kementerian Agama Republik Indonesia bersama dengan Kementerian Pendidikan dan Kebudayaan merupakan kementerian yang bertugas mengelola pendidikan di Indonesia. Kementerian Pendidikan dan
Kebudayaan mengelola pendidikan umum, sedangkan Kementerian Agama mengelola pendidikan agama dan keagamaan (Direktorat Pendidikan Madrasah, 2014).

Lembaga pendidikan berbasis Islam di Kabupaten Cilacap berjumlah cukup banyak dan tersebar di seluruh wilayah Kabupaten Cilacap. Namun berdasarkan observasi dan survai pendahuluan yang telah dilakukan, informasi tentang lembaga pendidikan berbasis Islam di Kabupaten Cilacap masih sedikit diketahui oleh masyarakat. Salah satu faktor yang menyebabkan hal ini adalah ketersediaan data yang sedikit dan tidak lengkap, sedangkan kebutuhan informasi masyarakat cukup tinggi.

Hasil observasi menunjukkan bahwa ketersediaan data sekolah berbasis Islam di Cilacap dalam jaringan internet sedikit jumlahnya dan tidak lengkap. Situs-situs yang menyediakan data sekolah Islam tersebut hanya memuat beberapa data jenjang sekolah saja. Disamping itu, diantara situs-situs tersebut belum ada yang memiliki fitur penunjuk lokasi sekolah. Kemudian hasil survai pendahuluan menunjukkan bahwa kebutuhan masyarakat Cilacap mengenai informasi sekolah Islam cukup tinggi.

Berdasarkan hasil yang diperoleh tersebut, implementasi sistem informasi geografis diharapkan dapat memenuhi kebutuhan informasi masyarakat Cilacap. Sistem informasi geografis ini dirancang dan dibangun untuk menyediakan informasi lokasi dan profil tentang lembaga pendidikan berbasis Islam yang ada di Kabupaten Cilacap secara lebih lengkap. Sistem informasi geografis dibangun berbasis web dengan menggunakan bahasa pemrograman PHP, basis data MySQL, dan basis peta Google Maps API.

\section{B. Rumusan Masalah}

Rumusan masalah yang dapat diambil sebagai dasar untuk melaksanakan penelitian ini adalah:

"Bagaimana merancang dan membangun suatu aplikasi yang dapat menjadi alternatif solusi penyedia informasi tentang lembaga pendidikan berbasis Islam yang ada di Kabupaten Cilacap?"

\section{Batasan Masalah}

Penyusunan tugas akhir ini mempunyai batasanbatasan masalah sebagai berikut:

- Sistem informasi geografis (SIG) ini dirancang untuk menampilkan informasi obyek/sarana lembaga pendidikan berbasis Islam yang ada di Kabupaten Cilacap. 
- SIG ini berisi informasi lokasi dan profil lembaga pendidikan berbasis Islam yang ada di Kabupaten Cilacap.

- Data lembaga pendidikan yang dimuat dalam SIG adalah data untuk Raudatul Athfal, Pendidikan Madrasah, Perguruan Tinggi, dan Pondok Pesantren.

- Data lembaga pendidikan yang diteliti merupakan data yang diambil dari Kementerian Agama Kabupaten Cilacap.

- Implementasi SIG ini menggunakan basis web.

- Perangkat yang digunakan dalam perancangan dan implementasi SIG ini adalah bahasa pemrograman PHP, basis data MySQL, dan basis peta Google Maps API.

\section{Tujuan Penelitian}

Perancangan dan penelitian sistem informasi geografis ini mempunyai tujuan untuk membangun aplikasi yang menyediakan informasi lokasi dan profil tentang lembaga pendidikan berbasis Islam yang ada di Kabupaten Cilacap.

\section{LANDASAN TEORI}

A. Lembaga Pendidikan Berbasis Islam

Menurut sejarah perkembangan pendidikan Islam di Indonesia, lembaga pendidikan berbasis Islam yang pertama adalah pesantren. Pesantren adalah tempat para murid (santri) untuk mendalami ilmu agama. Ketika pemerintah Belanda memerlukan tenaga terampil untuk membantu administrasi pemerintah jajahan di Indonesia, maka diperkenalkanlah jenis pendidikan yang berorientasi pada pekerjaan (Direktorat Pendidikan Madrasah, 2014).

\section{B. Sistem Informasi}

Sistem adalah sekumpulan komponen yang saling berhubungan dan bekerja sama untuk mencapai suatu tujuan (Sommerville, 2003). Informasi adalah kumpulan data yang diolah menjadi bentuk yang lebih berguna dan lebih berarti bagi yang menerima (Aziz \& Pujiono, 2006).

\section{Sistem Informasi Geografis}

Terdapat banyak definisi SIG dari berbagai sumber pustaka, hingga saat ini belum ada kesepakatan mengenai definisi SIG yang baku.Berikut adalah beberapa definisi SIG menurut beberapa sumber pustaka:

- SIG atau GIS adalah suatu bentuk sistem informasi yang menyajikan informasi dalam bentuk grafis dengan menggunakan peta sebagai antarmuka. SIG tersusun atas konsep beberapa lapisan (layer) dan relasi (Aziz \& Pujiono, 2006).

- SIG adalah sistem komputer yang digunakan untuk mengumpulkan, memeriksa, mengintegrasikan, dan menganalisis informasi-informasi yang berhubungan dengan permukaan bumi (Demers, 1997).

- SIG adalah kombinasi perangkat keras dan perangkat lunak sistem komputer yang memungkinkan pengguna untuk mengelola (manage), menganalisis, dan memetakan informasi spasial berikut data atributnya (data deskriptif) dengan akurasi kartografis (---, 2000).
1) Subsistem SIG

SIG merupakan suatu sistem yang terdiri atas beberapa subsistem yang satu sama lainnya saling terkait. Secara garis besar subsistem di dalam SIG terdiri atas empat, yaitu sebagai berikut (Prahasta, 2009):
a) Data Input
b) Data Output
c) Data Management
d) Data Manipulation \& Analysis

\section{2) Komponen SIG}

SIG merupakan salah satu sistem yang kompleks dan pada umumnya terintegrasi dengan lingkungan sistem komputer lainnya di tingkat fungsional dan jaringan. Namun demikian ada juga SIG yang berdiri sendiri (stand-alone). SIG sebagai sistem terdiri dari beberapa komponen sebagai berikut:
a) Perangkat Keras
b) Perangkat Lunak
c) Data \& Informasi Geografi (Data spasial atau data keruangan dan Data atribut)
d) Manajemen

\section{Model Proses Perangkat Lunak: Model Air Terjun (Waterfall)}

Model waterfall adalah model yang mengambil kegiatan proses dasar seperti spesifikasi, pengembangan, validasi, dan evolusi, dan merepresentasikannya ke dalam fase-fase proses yang berbeda seperti spesifikasi persyaratan, perancangan perangkat lunak, implementasi, pengujian, dan seterusnya (Sommerville, 2003). Model waterfall merupakan pendekatan perkembangan perangkat lunak yang sistematik dan sekuensial/berurutan dimulai dari analisis, desain, kode, pengujian, dan pemeliharaan (Pressman, 2002).

Tahap-tahap utama dari model waterfall memetakan kegiatan-kegiatan pengembangan dasar perangkat lunak, yang digambarkan seperti pada Gambar 1 berikut.

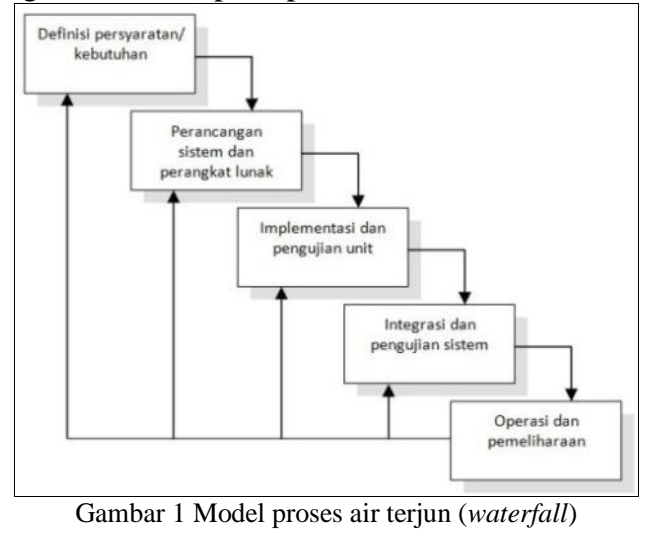

\section{E. PHP (PHP: Hypertext Preprocessor)}

PHP merupakan bahasa standar yang digunakan dalam dunia situs web. PHP adalah bahasa program yang berbentuk skrip yang diletakkan di dalam server web. Dalam hal ini, aplikasi pada umumnya akan memberikan hasil pada perambah web, tetapi prosesnya secara keseluruhan dijalankan dan dikerjakan di server web (Nugroho, 2004). 


\section{F. HTML}

HTML merupakan sekumpulan simbol-simbol atau tag-tag yang dituliskan dalam sebuah berkas yang digunakan untuk menampilkan halaman pada perambah web (Anhar, 2010). HTML (Hypertext Markup Languange) adalah bahasa pemrograman untuk aplikasi standar web, yang bersifat terbuka, dan memiliki dukungan perambah serta multi platform (Dewanto, 2006).

\section{G. CSS}

CSS (Cascading Style Sheets) adalah salah satu fasilitas yang diberikan untuk pemrograman HTML di dalam pengaturan/perancangan tampilan web menjadi lebih baik. CSS memungkinkan pengaturan posisi secara absolut, merubah warna, besar ukuran huruf, margin, dan sebagainya (Dewanto, 2006).

\section{H. JavaScript}

JavaScript adalah bahasa skrip yang ditempelkan pada kode HTML dan diproses pada sisi klien, yang menjadikan kemampuan dokumen HTML menjadi lebih luas (Kadir, 2003). JavaScript merupakan bahasa yang berbentuk kumpulan skrip yang berfungsi untuk memberikan tampilan yang tampak lebih interaktif pada dokumen web (Wahana, 2010).

\section{MySQL}

MySQL (My Structure Query Languange) atau yang biasa dibaca "mai-se-kuel" adalah sebuah program pembuat basis data (DBMS: Database Management System) yang bersifat sumber terbuka (Nugroho, 2004). MySQL merupakan program pengakses basis data yang bersifat jaringan sehingga dapat digunakan untuk aplikasi banyak pengguna. Saat ini basis data MySQL telah digunakan hampir oleh semua pemrogram basis data, terutama dalam pemrograman web.

\section{J. Google Maps dan Google Maps API}

Google Maps merupakan layanan penampil peta dunia berkapasitas TeraByte yang berisi citra satelit dan data jalan yang disediakan oleh Google secara gratis (Purvis, Sambells, \& Turner, 2006).

\section{1) Cara Kerja Google Maps}

Google Maps dibuat dengan menggunakan kombinasi dari gambar peta, basis data, serta obyekobyek interaktif yang dibuat dengan bahasa pemrograman HTML, JavaScript dan AJAX, serta beberapa bahasa pemrograman lainnya.

Gambar-gambar yang muncul pada peta merupakan hasil komunikasi dengan basis data pada server web Google untuk menampilkan gabungan dari potonganpotongan gambar yang diminta. Keseluruhan citra yang ada diintegrasikan ke dalam basis data pada Server Google, yang nantinya akan dapat dipanggil sesuai kebutuhan/permintaan. Bagian-bagian gambar map merupakan gabungan dari potongan gambar-gambar bertipe PNG yang disebut tile yang berukuran 256 x 256 pixel (Amri, 2015).

\section{2) Google Maps API}

Bahasa pemrograman yang digunakan oleh Google Maps yang terdiri dari HTML, JavaScript, dan AJAX serta XML, memungkinkan untuk menampilkan peta Google Maps di situs web lain. Google menyediakan layanan Google Maps API yang memungkinkan parapengembang untuk mengintegrasikan Google Maps ke dalam situs web masing-masing dengan menambahkan data point sendiri.

Agar aplikasi Google Maps dapat muncul di situs web tertentu, diperlukan adanya API key. API key merupakan kode unik yang digenerasikan oleh Google untuk suatu situs web tertentu, agar server Google Maps dapat mengenali (Amri, 2015).

\section{Perancangan Sistem}

\section{A. Analisis Kebutuhan}

Penyusunan analisis kebutuhan sistem dilakukan untuk mengetahui dan menentukan aspek-aspek apa saja yang sebaiknya dimuat dalam sistem, sehingga sistem dapat optimal dalam memenuhi kebutuhan pengguna. Analisis kebutuhan sistem dilakukan dengan cara observasi dan membaca dokumen hasil survai.

\section{1) Kondisi Awal}

Kondisi awal menjelaskan gambaran keadaan mulamula sebelum pembangunan sistem.

a) Kondisi masyarakat Cilacap berdasarkan hasil survai

Gambar 2 dan Gambar 3 menunjukkan bahwa pencarian informasi sekolah melalui internet sudah menjadi salah satu pilihan masyarakat.

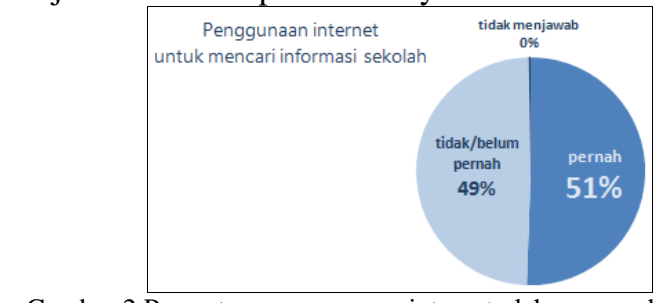

Gambar 2 Presentase penggunaan internet oleh masyarakat Cilacap untuk mencari informasi sekolah

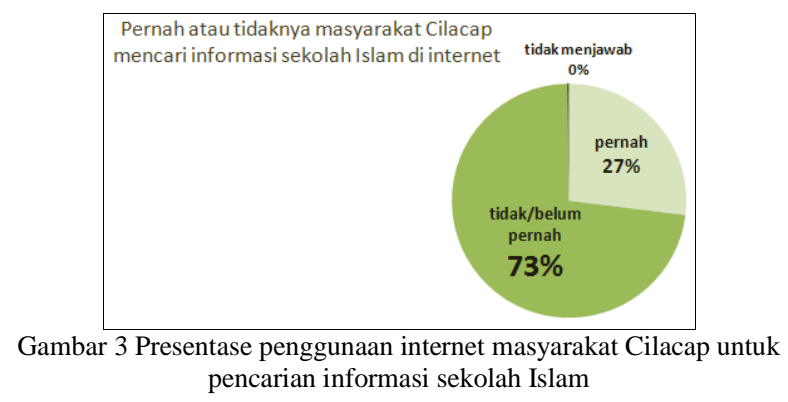

b) Data sekolah Islam di Cilacap

Data mengenai lembaga pendidikan dikelola dalam sistem yang baik di Kantor Kementerian Agama Kabupaten Cilacap. Data tersebut bersifat umum, masyarakat diperbolehkan untuk mengetahui dan mengakses (walaupun dengan syarat tertentu). Namun selama ini data tersebut hanya digunakan oleh pegawai internal untuk keperluan administrasi dan arsip, belum 
ada sarana bagi masyarakat untuk mengakses dan mengambil manfaat dari data tersebut.

Gambar 4 menunjukkan sampel data lembaga pendidikan yang terdapat dalam sistem informasi manajemen di Kementerian Agama Kabupaten Cilacap (Kemenag, 2014).

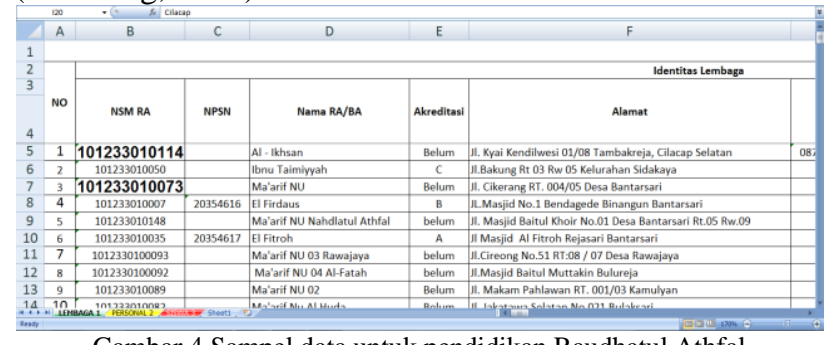

Gambar 4 Sampel data untuk pendidikan Raudhatul Athfal

Data tersebut merupakan data utama yang utuh atau lengkap, sehingga perlu dilakukan analisis agar data yang dimuat ke dalam sistem tidak berlebihan, namun informasi yang dibagikan kepada masyarakat umum cukup memadai. Dari proses analisis yang dilakukan pada data utama dan data hasil survai, dihasilkan beberapa data akan ditampilkan dalam sistem informasi geografis (selanjutnya disebut SIG Sekolah Islam), yaitu:

- Nama lembaga pendidikan

- Akreditasi

- Alamat situs web

- Fasilitas/ sarana dan prasarana

- Alamat lembaga pendidikan

- Foto/gambar (yang tersedia)

- Koordinat lintang (latitude) (hanya Admin)

- Koordinat bujur (longitude) (hanya Admin)

\section{2) Kebutuhan Fungsional}

Kebutuhan fungsional merupakan kebutuhan yang meliputi fungsi aplikasi dan berkaitan langsung dengan fitur-fitur yang terdapat pada aplikasi. Kebutuhan fungsional dari aplikasi SIG Sekolah Islam adalah sebagai berikut.

a) Aktor yang terlibat adalah Admin dan Pengunjung.

b) Admin dapat masuk ke dalam sistem (login) dan keluar dari sistem (logout). Fungsi tersebut bertujuan untuk membatasi akses pengguna terhadap data yang terdapat dalam sistem. Hanya pengguna yang mempunyai hak yang dapat mengelola dan mengubah data.

c) Admin dapat mengelola data lembaga pendidikan meliputi menambah data, mengubah data, dan menghapus data. Fungsi tersebut bertujuan agar data dalam sistem dapat dikelola dan diperbarui secara berkala.

d) Admin dapat mencari data lembaga pendidikan. Fungsi tersebut bertujuan agar data lembaga pendidikan dapat dicari dan selanjutnya dikelola dengan mudah.

e) Admin dapat melihat peta lokasi lembaga pendidikan sesuai dengan data yang telah dimasukkan ke dalam sistem. Fungsi tersebut bertujuan agar data yang sebelumnya dimasukkan telah dipastikan muncul dalam peta lokasi. f) Pengunjung dapat melihat peta lokasi lembaga pendidikan yang tersedia. Fungsi tersebut bertujuan agar memudahkan pengguna mengetahui lokasi lembaga pendidikan.

g) Pengunjung dapat melihat informasi lembaga pendidikan yang tersedia. Fungsi tersebut bertujuan agar memudahkan pengguna mengetahui profil lembaga pendidikan.

\section{3) Kebutuhan Non Fungsional}

Kebutuhan non fungsional merupakan kebutuhan yang tidak berkaitan langsung dengan fungsi dan fiturfitur aplikasi, melainkan merupakan batasan pada kebutuhan fungsional. Berikut merupakan kebutuhan non fungsional aplikasi SIG sekolah Islam.

a) Operasional

Sistem dapat diakses dari perangkat komputer.

b) Keamanan

Sistem memiliki fungsi login untuk memberikan akses kepada pengguna Admin.

\section{B. Desain Sistem}

Setelah analisis kebutuhan dilakukan, selanjutnya dilakukan proses desain sistem yang meliputi desain teknis dalam pembangunan perangkat lunak, pemodelan perangkat lunak, dan desain antarmuka.

1) Spesifikasi Teknis

Proses spesifikasi teknis menjelaskan tentang desain dan kebutuhan teknis yang digunakan untuk membangun aplikasi SIG sekolah Islam.

a) Arsitektur Sistem

Arsitektur SIG sekolah Islam ditunjukkan pada Gambar 5.

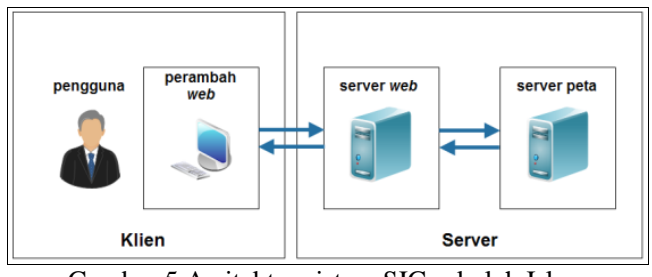

b) Arsitektur Aplikasi

Arsitektur aplikasi SIG sekolah Islam ditunjukkan pada Gambar 6.

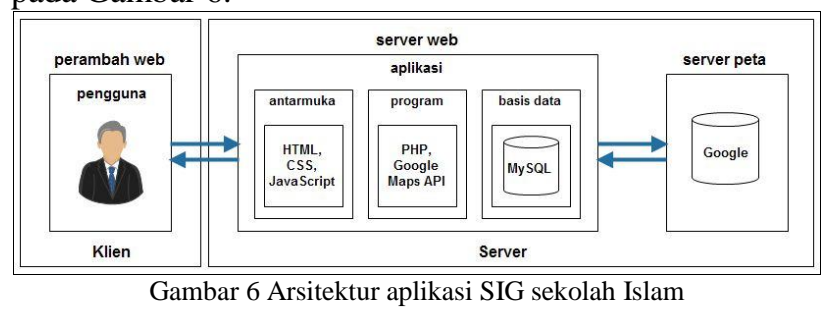

c) Kebutuhan Perangkat Keras

Kebutuhan perangkat keras minimal untuk menjalankan aplikasi ini adalah perangkat komputer yang mempunyai dan dapat menjalankan fitur perambah web.

d) Kebutuhan Perangkat Lunak

Kebutuhan perangkat lunak minimal untuk menjalankan aplikasi ini adalah perangkat komputer yang mempunyai perambah web yang telah terinstalasi plugin JavaScript. 
2) Pemodelan Perangkat Lunak

Aplikasi SIG Sekolah Islam menggunakan aplikasi sistem pemrograman terstruktur, oleh karena itu digunakan pemodelan perangkat lunak menggunakan Data Flow Diagram (DFD). Selain perangkat lunak, pemodelan juga dilakukan terhadap data yang diolah dalam sistem. Pemodelan data dilakukan dengan Entity Relationship Diagram (ERD).

a) Desain ERD

Entity Relationship Diagram (ERD) merupakan metode pemodelan terhadap data yang akan diolah oleh sistem dan selanjutnya disimpan dalam basis data. ERD aplikasi SIG Sekolah Islam ditunjukkan pada Gambar 7.



Gambar 7 Desain ERD SIG sekolah Islam

b) Desain DFD

Diagram aliran data atau DFD merupakan diagram yang dibuat untuk mengetahui jalannya proses aliran data pada sistem/aplikasi.

- Dekomposisi Diagram

Dekomposisi diagram aplikasi SIG Sekolah Islam ditunjukkan pada Gambar 8.

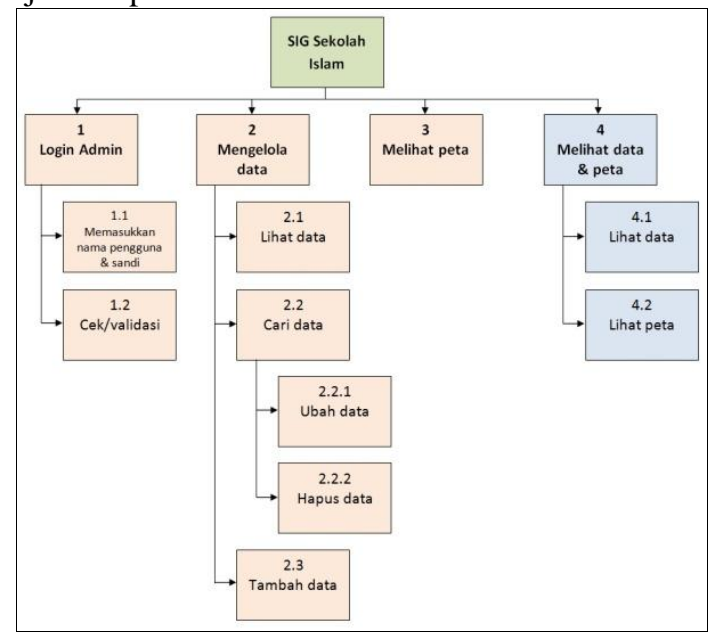

Gambar 8 Dekomposisi diagram SIG sekolah Islam

- Diagram Konteks

Context Diagram atau Diagram Konteks merupakan diagram level tertinggi dari DFD, yang menggambarkan keseluruhan kondisi sistem/ aplikasi yang akan dirancang. Gambar 9 menunjukkan diagram konteks SIG sekolah Islam.

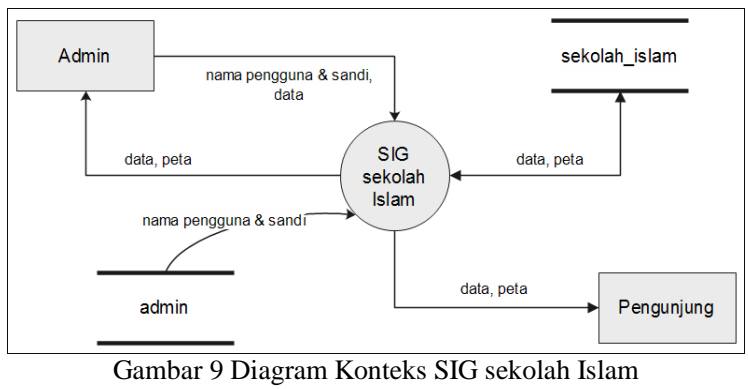

\section{- DFD Level 0}

DFD level 0 merupakan diagram dekomposisi dari diagram konteks. Diagram ini menggambarkan lebih rinci proses yang ada, dan data yang mengalir diantara proses dan basis data, serta entitas yang terlibat dalam proses tersebut. Gambar 10 menunjukkan DFD level 0 SIG sekolah Islam.

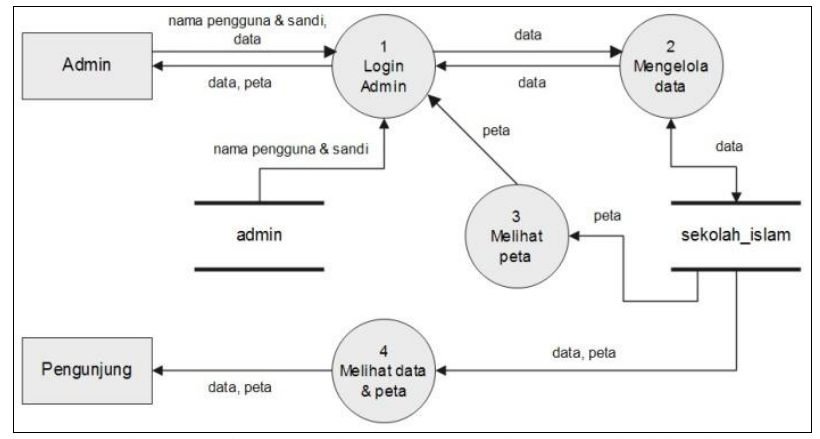

Gambar 10 Diagram Aliran Data Level 0 SIG sekolah Islam

\section{- DFD Level 1}

DFD level 1 merupakan diagram dekomposisi dari diagram level 0. Diagram ini menggambarkan proses yang lebih kecil (subproses) dari proses utama yang ada pada diagram level 0. Gambar 11 menunjukkan DFD level 1 proses 1(login Admin) SIG sekolah Islam.

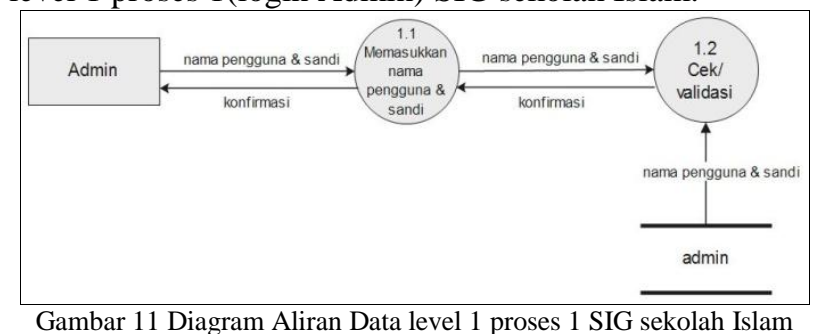

Gambar 12 menunjukkan DFD level 1 proses 2 (mengelola data (Admin)) SIG sekolah Islam.

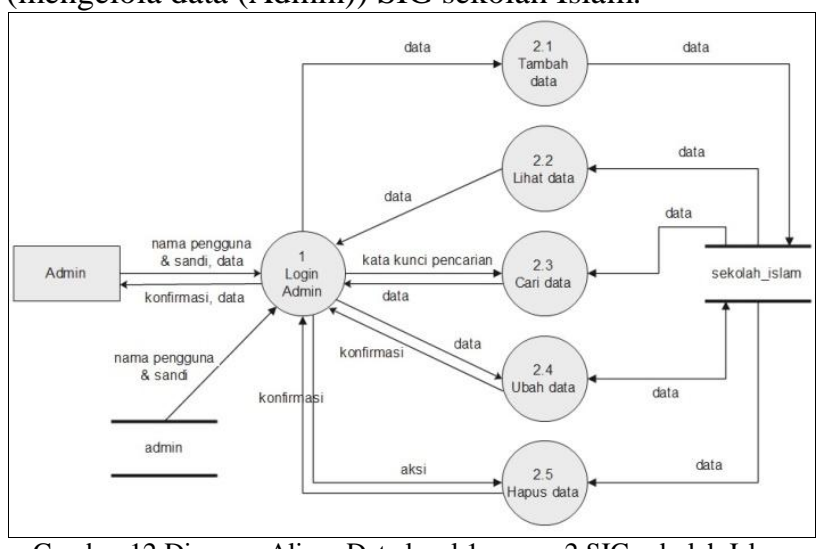

Gambar 12 Diagram Aliran Data level 1 proses 2 SIG sekolah Islam 
Gambar 13 menunjukkan DFD level 1 proses 4 (melihat data dan/atau peta lokasi (Pengunjung)) SIG sekolah Islam.

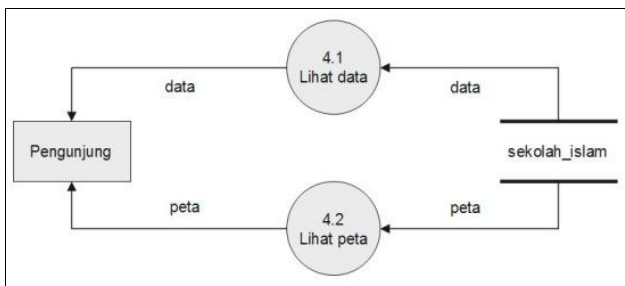

Gambar 13 Diagram Aliran Data level 1 proses 4 SIG sekolah Islam

- DFD Level 2

DFD level 2 merupakan diagram dekomposisi dari diagram level 1. Gambar 14 menunjukkan DFD level 2 proses 2.3 (cari data (Admin)) SIG sekolah Islam.

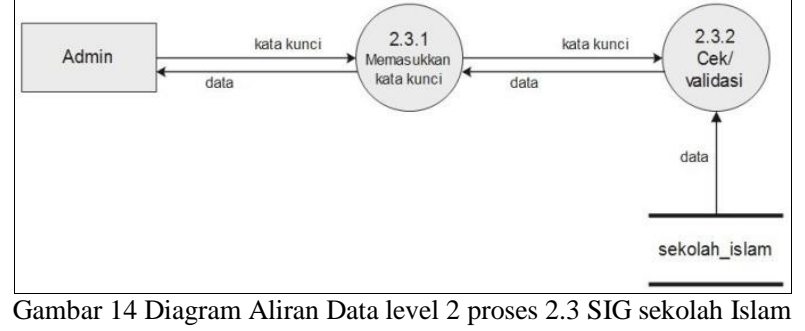

- Kamus Data

Kamus data berfungsi untuk mendeskripsikan rincian aliran data atau informasi yang mengalir dalam sistem, elemen-elemen data, berkas, maupun basis data (tempat penyimpanan) dalam DFD. Tabel 1 menunjukkan salah satu kamus data pada perancangan SIG sekolah Islam.

Tabel 1 Kamus data Proses 2: Mengelola data (2.1 Tambah data (1))

\begin{tabular}{|c|c|}
\hline \multicolumn{2}{|r|}{ Kamus Data } \\
\hline Nama arus data & : data \\
\hline Alias & : tambah data sekolah \\
\hline Bentuk data & : pencatatan/ input formulir \\
\hline Arus Data & : 1 Login Admin - 2.1 Tambah data \\
\hline Penjelasan & : menambahkan data sekolah \\
\hline Periode & : setiap ada pembaruan pada data utama \\
\hline Volume & $:-$ \\
\hline Stuktur Data & 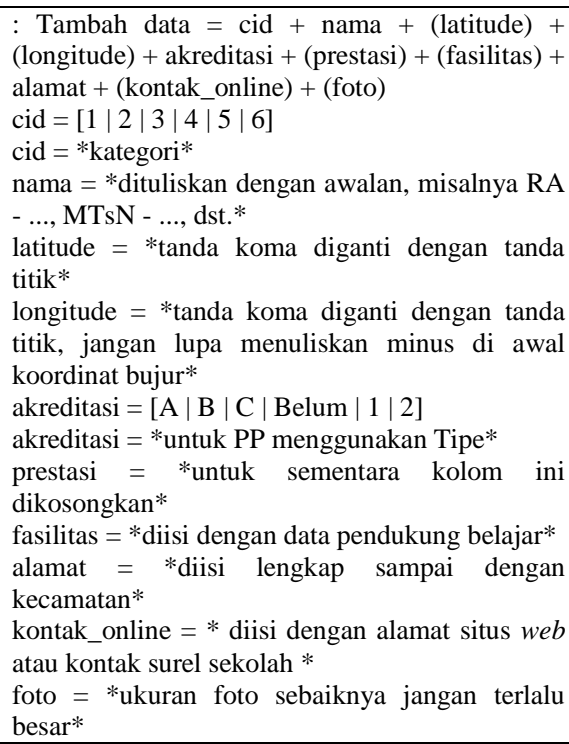 \\
\hline
\end{tabular}

3) Desain Antarmuka

Gambar 15 menunjukkan desain rancangan antarmuka SIG sekolah Islam.

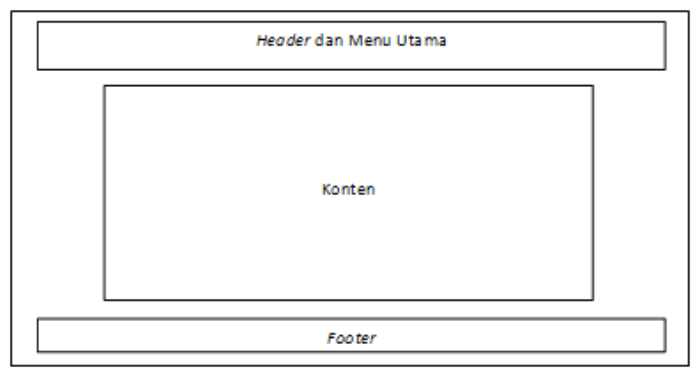

Gambar 15 Rancangan antarmuka SIG sekolah Islam

Berdasarkan analisis kebutuhan, antarmuka konten dikelompokkan menjadi 4 kategori, yaitu:

a) Login form

b) Tabel data

c) Form data

d) Penampil peta

\section{PEMBAHASAN}

\section{A. Implementasi}

Tahap implementasi merupakan tahap lanjut setelah dilakukan perancangan sistem. Setelah perancangan selesai dilaksanakan, maka pembangunan aplikasi dapat segera dilakukan.

\section{1) Implementasi Basis Data}

Implementasi basis data merupakan tahap pembuatan tabel-tabel yang dibutuhkan oleh aplikasi SIG untuk menyimpan data. Tabel-tabel ini dibuat menggunakan basis data MySQL melalui perangkat lunak pembantu PHPMyAdmin. Basis data diberi nama dengan nama sigsiclp. Tabel yang dibuat berjumlah 3 buah, yaitu tabel pengguna (pengguna), tabel kategori (kategori_sekolah), dan tabel sekolah (sekolah_islam).

\section{2) Implementasi SIG}

Inti dari aplikasi SIG sekolah Islam adalah penunjuk lokasi dan penampil data profil sekolah Islam. Aplikasi SIG sekolah Islam dibangun berbasis web, menggunakan bahasa pemrograman PHP, basis data MySQL, dan basis peta Google Maps API.

Tabel 2 berikut merupakan pencapaian pembangunan fungsi aplikasi sesuai dengan kebutuhan fungsional.

\begin{tabular}{|c|c|c|c|}
\hline No. & Pengguna & Fungsi & $\begin{array}{c}\text { Pencapaian } \\
\text { pembangunan }\end{array}$ \\
\hline \multirow{2}{*}{1.} & \multirow{2}{*}{ Admin } & $\begin{array}{l}\text { masuk ke dalam sistem } \\
(\text { login })\end{array}$ & \multirow{2}{*}{ Selesai } \\
\hline & & $\begin{array}{lll}\begin{array}{l}\text { keluar } \\
(\text { logout })\end{array} & \text { dari } & \text { sistem } \\
\end{array}$ & \\
\hline \multirow{3}{*}{2.} & \multirow{3}{*}{ Admin } & menambah data & \multirow{3}{*}{ Selesai } \\
\hline & & mengubah data & \\
\hline & & menghapus data & \\
\hline 3. & Admin & mencari data & Selesai \\
\hline 4. & Admin & melihat peta lokasi & Selesai \\
\hline 5. & Pengunjung & melihat peta lokasi & Selesai \\
\hline 6. & Pengunjung & $\begin{array}{l}\text { melihat data profil } \\
\text { lembaga pendidikan }\end{array}$ & Selesai \\
\hline
\end{tabular}


Gambar 16, Gambar 17, dan Gambar 18 berikut merupakan beberapa tampilan implementasi SIG sekolah Islam.

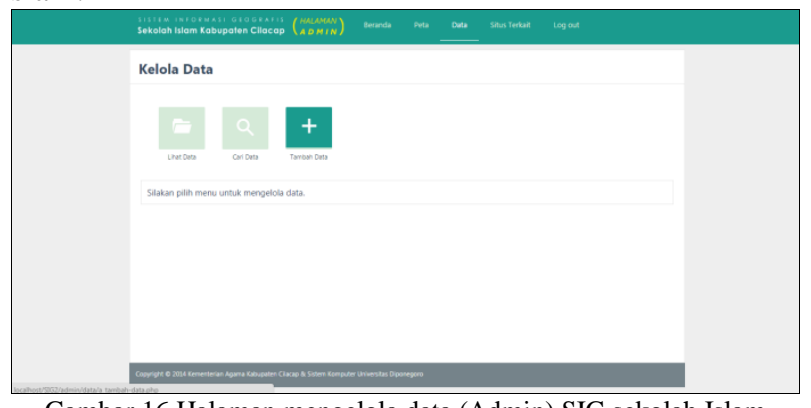

Gambar 16 Halaman mengelola data (Admin) SIG sekolah Islam

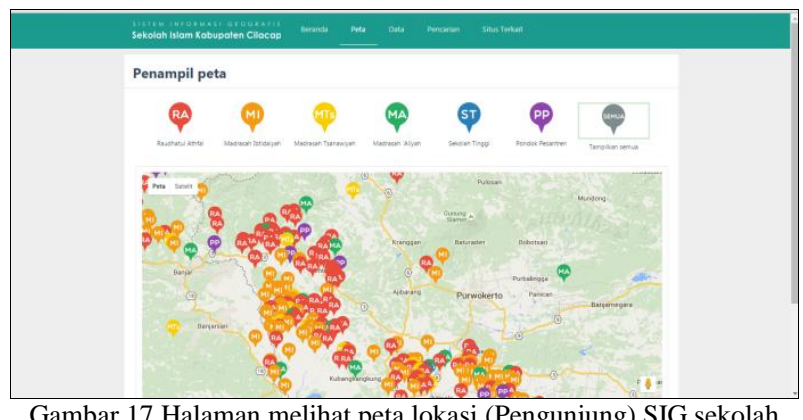

Gambar 17 Halaman melihat peta lokasi (Pengunjung) SIG sekolah Islam

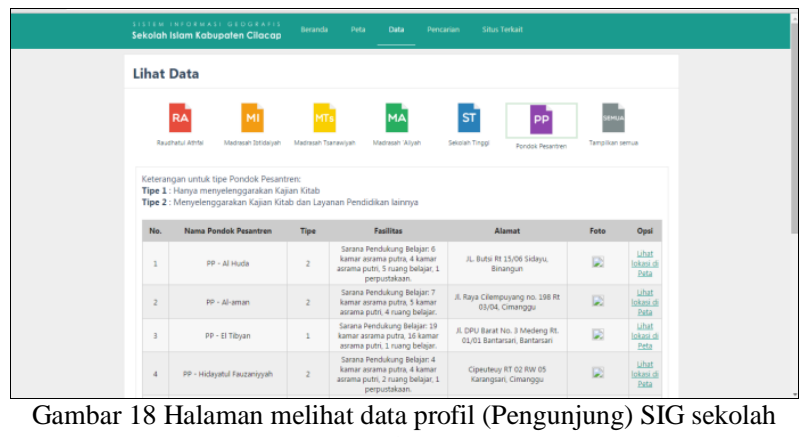
Islam

\section{B. Pengujian Unit}

Setelah aplikasi selesai dibangun, tahap selanjutnya adalah pengujian perangkat lunak. Terdapat 2 tahap pengujian perangkat lunak pada model proses waterfall, yaitu pengujian unit dan pengujian sistem.

Pengujian unit dilakukan untuk memastikan bahwa setiap unit atau fungsi perangkat lunak telah memenuhi spesifikasinya. Metode pengujian yang digunakan adalah black-box atau kotak hitam. Pengujian kotak hitam merupakan pengujian yang dilakukan terhadap spesifikasi produk.

Pengujian unit dilakukan untuk mengetahui apakah semua fungsi perangkat lunak telah berjalan semestinya sesuai dengan kebutuhan fungsional yang telah didefinisikan. Tabel 3 menunjukkan hasil pengujian unit aplikasi SIG sekolah Islam.
Tabel 3 Daftar pengujian unit aplikasi SIG sekolah Islam

\begin{tabular}{|c|c|c|c|}
\hline Pengujian & Tindakan & $\begin{array}{c}\text { Hasil yang } \\
\text { diharapkan }\end{array}$ & Analisis \\
\hline Login & $\begin{array}{l}\text { Memasukkan nama } \\
\text { pengguna dan kata } \\
\text { sandi, kemudian } \\
\text { menekan tombol } \\
\text { Login. }\end{array}$ & $\begin{array}{lr}\text { Jika } & \text { login } \\
\text { berhasil, } & \text { akan } \\
\text { ditampilkan } & \\
\text { halaman beranda } \\
\text { Admin. } \\
\text { gagal, Jika } \\
\text { ditampilkan pesan } \\
\text { kegagalan. }\end{array}$ & $\begin{array}{c}\text { Sukses, } \\
\text { fungsi } \\
\text { berhasil } \\
\text { dijalankan }\end{array}$ \\
\hline $\begin{array}{l}\text { Menambah } \\
\text { data sekolah } \\
\text { (1) }\end{array}$ & $\begin{array}{lr}\text { Memilih } & \text { menu } \\
\text { Data }> & \text { Tambah } \\
\text { Data }> & \text { Gunakan } \\
\text { form } & \text { input } \\
\text { manual. } & \text { Kemudian } \\
\text { mengisi } & \text { form. } \\
\text { Kemudian } & \\
\text { menekan tombol } & \text { tom } \\
\text { Simpan data. }\end{array}$ & $\begin{array}{lr}\text { Koneksi ke } & \text { basis } \\
\text { data } & \text { dapat } \\
\text { dilakukan } & \text { dan } \\
\text { proses } & \\
\text { penambahan data } \\
\text { berjalan dengan } \\
\text { baik. } \\
\text { berhasil Data } \\
\text { ditambahkan. }\end{array}$ & $\begin{array}{c}\text { Sukses, } \\
\text { fungsi } \\
\text { berhasil } \\
\text { dijalankan }\end{array}$ \\
\hline $\begin{array}{l}\text { Menambah } \\
\text { data sekolah } \\
\text { (2) }\end{array}$ & $\begin{array}{lr}\text { Memilih } & \text { menu } \\
\text { Data > } & \text { Tambah } \\
\text { Data }> & \text { Gunakan } \\
\text { form } & \text { unggah } \\
\text { berkas. } & \text { Kemudian } \\
\text { memilih } & \text { berkas. } \\
\begin{array}{lr}\text { Kemudian } \\
\text { menekan }\end{array} & \text { tombol } \\
\text { Unggah. } & \end{array}$ & $\begin{array}{lr}\text { Koneksi } & \text { ke } \\
\text { data } & \text { dapis } \\
\text { dilakukan } & \text { dan } \\
\text { proses } & \\
\text { penambahan data } \\
\text { berjalan dengan } \\
\text { baik. rata } \\
\text { berhasil diunggah. }\end{array}$ & $\begin{array}{c}\text { Sukses, } \\
\text { fungsi } \\
\text { berhasil } \\
\text { dijalankan }\end{array}$ \\
\hline $\begin{array}{l}\text { Mengubah } \\
\text { data }\end{array}$ & $\begin{array}{l}\text { Menekan pilihan } \\
\text { Ubah pada tabel } \\
\text { data. Kemudian } \\
\text { mengisi form. } \\
\text { Kemudian } \\
\text { menekan tombol } \\
\text { Simpan data. }\end{array}$ & $\begin{array}{l}\text { Perubahan data } \\
\text { berhasil, data } \\
\text { lama diperbarui } \\
\text { dengan data yang } \\
\text { baru. }\end{array}$ & $\begin{array}{c}\text { Sukses, } \\
\text { fungsi } \\
\text { berhasil } \\
\text { dijalankan }\end{array}$ \\
\hline $\begin{array}{l}\text { Menghapus } \\
\text { data }\end{array}$ & $\begin{array}{l}\text { Menekan pilihan } \\
\text { Hapus. Kemudian } \\
\text { menekan tombol } \\
\text { konfirmasi hapus. }\end{array}$ & $\begin{array}{ll}\text { Data } & \text { berhasil } \\
\text { dihapus. } & \end{array}$ & $\begin{array}{c}\text { Sukses, } \\
\text { fungsi } \\
\text { berhasil } \\
\text { dijalankan }\end{array}$ \\
\hline Mencari data & $\begin{array}{lr}\text { Memilih } & \text { menu } \\
\text { Data > Cari Data. } \\
\text { Kemudian } & \text { mengisi } \\
\text { kata } & \text { kunci } \\
\text { pencarian } & \text { pada } \\
\text { form. Kemudian } \\
\text { menekan } r \text { tombol } \\
\text { OK. }\end{array}$ & $\begin{array}{lr}\text { Semua } & \text { data } \\
\text { sekolah } & \text { yang } \\
\text { cocok dengan kata } \\
\text { kunci } & \text { akan } \\
\text { ditampilkan } & \text { pada } \\
\text { tabel data. } & \text { Jika } \\
\text { kata kunci } & \text { tidak } \\
\text { cocok, } & \text { akan } \\
\text { ditampilkan pesan } \\
\text { bahwa rata } \\
\text { dengan kata kunci } \\
\text { tersebut tidak ada. }\end{array}$ & $\begin{array}{c}\text { Sukses, } \\
\text { fungsi } \\
\text { berhasil } \\
\text { dijalankan }\end{array}$ \\
\hline $\begin{array}{l}\text { Melihat peta } \\
\text { lokasi }\end{array}$ & $\begin{array}{lr}\text { Memilih } & \text { menu } \\
\text { Peta. } & \text { Kemudian } \\
\text { memilih } & \text { kategori } \\
\text { sekolah. } & \end{array}$ & \begin{tabular}{lr}
\multicolumn{2}{l}{ Ditampilkan } \\
halaman & penampil \\
peta & penunjuk \\
lokasi & sekolah \\
Islam & sesuai \\
dengan & kategori \\
yang telah dipilih.
\end{tabular} & \begin{tabular}{|} 
Sukses, \\
fungsi \\
berhasil \\
dijalankan
\end{tabular} \\
\hline $\begin{array}{l}\text { Melihat } \\
\text { informasi } \\
\text { profil } \\
\text { lembaga } \\
\text { pendidikan }\end{array}$ & $\begin{array}{lr}\text { Memilih } & \text { menu } \\
\text { Data. } & \text { Kemudian } \\
\text { memilih } & \text { kategori } \\
\text { sekolah. } & \end{array}$ & $\begin{array}{l}\text { Ditampilkan } \\
\text { halaman penampil } \\
\text { informasi } \\
\text { Islam sekolah } \\
\text { dengan kesuai } \\
\text { yang telah dipilih. }\end{array}$ & $\begin{array}{c}\text { Sukses, } \\
\text { fungsi } \\
\text { berhasil } \\
\text { dijalankan }\end{array}$ \\
\hline Logout & $\begin{array}{l}\text { Menekan } \\
\text { Log out. }\end{array}$ & $\begin{array}{l}\text { Proses keluar dari } \\
\text { sistem berhasil, } \\
\text { dan selanjutnya } \\
\text { ditampilkan } \\
\text { halaman utama } \\
\text { situs SIG sekolah } \\
\text { Islam. }\end{array}$ & \begin{tabular}{|c|} 
Sukses, \\
fungsi \\
berhasil \\
dijalankan
\end{tabular} \\
\hline
\end{tabular}




\section{Pengujian Sistem}

Pengujian yang kedua adalah pengujian sistem. Pengujian sistem dilakukan untuk memastikan masingmasing fungsi yang ada dalam aplikasi SIG sekolah Islam dapat berjalan baik secara keseluruhan. Fungsi-fungsi tersebut diintegrasikan, dan diuji sebagai sistem yang lengkap untuk menjamin bahwa kebutuhan sistem terpenuhi. Pengujian sistem dilakukan dengan contoh simulasi penggunaan aplikasi SIG sekolah Islam.

Simulasi penggunaan aplikasi dilakukan dalam 2 sisi pengguna, yaitu Admin mengelola data dan Pengunjung mencari data. Kedua simulasi yang dijalankan menunjukkan bahwa sistem dapat terintegrasi dan berjalan baik dalam melakukan suatu pekerjaan. Hasil simulasi pengujian sistem dirangkum pada Tabel 4.

Tabel 4 Rangkuman simulasi pengujian sistem aplikasi SIG sekolah Islam

\begin{tabular}{|l|l|l|}
\hline \multicolumn{1}{|c|}{ Skenario } & \multicolumn{1}{|c|}{ Fungsi Terkait } & \multicolumn{1}{|c|}{ Analisis } \\
\hline $\begin{array}{l}\text { Admin } \\
\text { mengelola } \\
\text { data }\end{array}$ & $\begin{array}{l}\text { Login, menambah data, melihat } \\
\text { peta lokasi, mengubah data, } \\
\text { menghapus data, logout. }\end{array}$ & $\begin{array}{l}\text { Berjalan } \\
\text { dengan baik }\end{array}$ \\
\hline $\begin{array}{l}\text { Pengunjung } \\
\text { mencari data }\end{array}$ & $\begin{array}{l}\text { Melihat peta lokasi, melihat data } \\
\text { profil sekolah, mencari data } \\
\text { sekolah. }\end{array}$ & $\begin{array}{l}\text { Berjalan } \\
\text { dengan baik }\end{array}$ \\
\hline
\end{tabular}

D. Pengujian Aplikasi oleh Pengguna

Setelah aplikasi selesai dibangun dan sudah memenuhi kebutuhan sistem, pengujian selanjutnya adalah pengujian aplikasi oleh pengguna. Dalam hal ini pengguna aplikasi SIG sekolah Islam adalah masyarakat Cilacap.

Telah dipilih secara acak 30 responden untuk mencoba menggunakan aplikasi SIG sekolah Islam. Setelah mencoba aplikasi, responden diharuskan mengisi kuisioner tanggapan mengenai aplikasi.

1) Perhitungan Interval atau Rasio Persetujuan Aplikasi SIG Sekolah Islam dengan Skala Likert

Tabel 5 menunjukkan hasil pengisian kuisioner tanggapan mengenai aplikasi SIG sekolah Islam.

Tabel 5 Perhitungan nilai akhir hasil pengisian kuisioner tanggapan aplikasi SIG sekolah Islam

\begin{tabular}{|c|c|c|c|}
\hline \multicolumn{1}{|c|}{ Pertanyaan } & Skor & $\begin{array}{c}\text { Interval/ } \\
\text { Rasio (\%) }\end{array}$ & Keterangan \\
\hline $\begin{array}{l}\text { 1. Apakah sistem informasi ini } \\
\text { sudah memuat informasi } \\
\text { sekolah Islam dengan jelas? }\end{array}$ & 92 & 76,67 & $\begin{array}{c}75 \%-100 \% \\
\text { (sangat) }\end{array}$ \\
\hline $\begin{array}{l}\text { 2. Apakah tampilan dari sistem } \\
\text { informasi geografis ini sudah } \\
\text { menarik? }\end{array}$ & 97 & 80,83 & $\begin{array}{c}75 \%-100 \% \\
\text { (sangat) }\end{array}$ \\
\hline $\begin{array}{l}\text { Apakah informasi yang } \\
\text { disediakan dalam sistem } \\
\text { informasi geografis ini sudah } \\
\text { lengkap? }\end{array}$ & 74 & 61,67 & $\begin{array}{c}50 \%- \\
74,99 \% \\
\text { (netral) }\end{array}$ \\
\hline $\begin{array}{l}\text { 4. Apakah sistem informasi } \\
\text { geografis ini mudah untuk } \\
\text { digunakan? }\end{array}$ & 95 & 79,17 & $\begin{array}{c}75 \%-100 \% \\
\text { (sangat) }\end{array}$ \\
\hline $\begin{array}{l}\text { 5. Apakah sistem pencarian } \\
\text { yang ada dalam sistem } \\
\text { informasi geografis ini cepat } \\
\text { dan mudah digunakan? }\end{array}$ & 94 & 78,33 & $\begin{array}{c}75 \%-100 \% \\
\text { (sangat) }\end{array}$ \\
\hline $\begin{array}{l}\text { 7. Apakah sistem informasi } \\
\text { geografis ini sudah sesuai } \\
\text { dengan yang } \\
\text { Bapak/Ibu/Adik harapkan? }\end{array}$ & 89 & 74,17 & $\begin{array}{c}50 \%- \\
\text { (netral) }\end{array}$ \\
\hline $\begin{array}{l}\text { Anata } \\
\text { (sangat) }\end{array}$ \\
\hline
\end{tabular}

Berdasarkan hasil perhitungan tersebut didapatkan hasil rasio tingkat persetujuan aplikasi SIG sekolah Islam sebesar 75,14\%, atau dengan interval $75 \%$ - $100 \%$ yaitu kategori "sangat" baik. Hasil tersebut dapat digambarkan seperti pada Gambar 19 berikut.

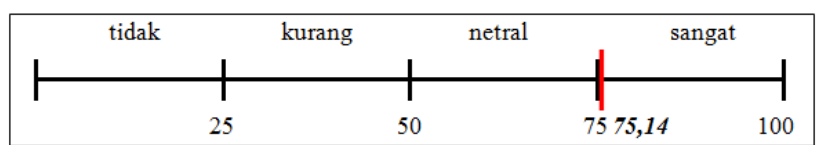

Gambar 19 Tingkat persetujuan terhadap aplikasi SIG sekolah Islam

2) Kelebihan dan kekurangan aplikasi

Berikut merupakan kelebihan aplikasi SIG sekolah Islam berdasarkan pengisian kuisioner oleh responden.

- Sangat menunjang untuk tambahan pengetahuan.

- Memudahkan responden untuk mencari data dan lokasi/alamat sekolah Islam di Cilacap.

- Semua responden berpendapat ingin menggunakan kembali aplikasi SIG sekolah Islam. Hasil ini ditunjukkan pada Gambar 20.

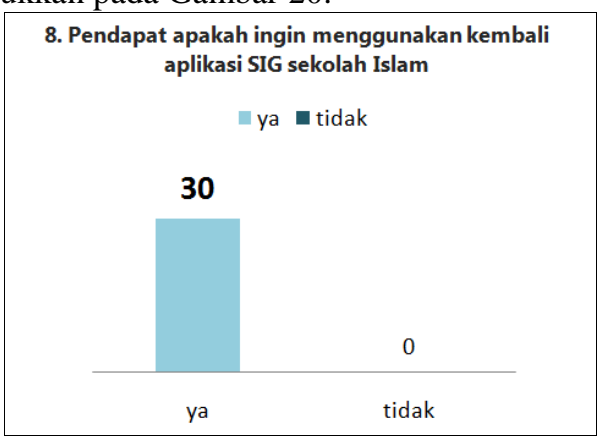

Gambar 20 Pendapat responden pada jawaban kuesioner nomor 8

Sedangkan kekurangan aplikasi SIG sekolah Islam menurut responden adalah sebagai berikut.

- Informasi yang ditampilkan belum lengkap.

- Peta masih kurang jelas dan membingungkan bagi pengguna anak-anak.

- Aplikasi kurang jelas dan navigasi membingungkan bagi pengguna anak-anak.

Gambar 21 menunjukkan bahwa sebanyak 27\% responden merasa kesulitan dalam cara pengoperasian aplikasi SIG sekolah Islam. Kemudian sebanyak $20 \%$ merasa kesulitan dalam menjalankan menu/navigasi aplikasi SIG sekolah Islam.

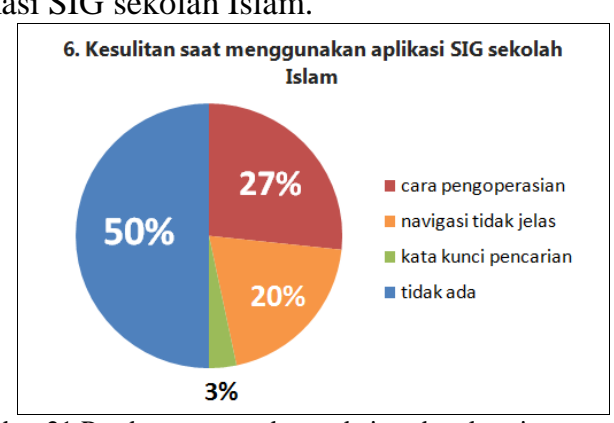

Gambar 21 Pendapat responden pada jawaban kuesioner nomor 6 


\section{PENUTUP}

\section{A. Kesimpulan}

Penelitian tugas akhir dengan topik SIG sekolah Islam ini menghasilkan kesimpulan sebagai berikut.

1) SIG sekolah Islam dapat menampilkan peta penunjuk lokasi sekolah Islam untuk pengguna dengan cepat dan praktis jika dibandingkan dengan pencarian melalui peta konvensional.

2) SIG sekolah Islam dapat menampilkan data sekolah Islam untuk pengguna lebih lengkap dan praktis jika dibandingkan dengan pencarian manual melalui mesin pencari di internet.

3) Data sekolah dalam SIG sekolah Islam dapat diperbarui sewaktu-waktu dengan mudah karena mempunyai halaman admin. Dengan pembaruan data yang mudah tersebut, data sekolah yang disediakan bersifat paling baru.

4) SIG sekolah Islam dapat dijangkau dengan mudah karena berbasis situs web. Pengguna hanya memerlukan perangkat yang mempunyai perambah $w e b$ dan koneksi internet yang stabil untuk mengakses SIG sekolah Islam.

5) Berdasarkan pengujian aplikasi yang telah dilakukan, hasil yang diperoleh menunjukkan bahwa aplikasi SIG sekolah Islam berhasil dibangun dengan baik. Aplikasi SIG sekolah Islam dapat menjadi salah satu rekomendasi dan alternatif solusi penyedia informasi tentang sekolah Islam di Kabupaten Cilacap.

B. Saran

Berikut adalah beberapa saran untuk penelitian tugas akhir dengan topik SIG sekolah Islam.

1) SIG sekolah Islam dapat dikembangkan ke dalam perangkat lunak yang responsif, sehingga memungkinkan untuk diakses melalui perangkat bergerak.

2) Penambahan menu Saran. Menu Saran diperlukan untuk menampung masukan-masukan atau pendapat mengenai aplikasi dari pengguna, yang bermanfaat untuk pengembangan aplikasi di waktu mendatang.

3) Informasi sekolah yang ditampilkan sebaiknya ditambah, hal ini disebabkan karena kelengkapan informasi sangat diharapkan oleh masyarakat.

\section{DAFTAR PUSTAKA}

[1] --http://www.cdm.com/Svcs/infomgt/GIS/gisbasic.htm, 11 Desember 2015

[2] Amri, M. S., Membangun Sistem Navigasi Di Surabaya Menggunakan Google Maps Api, repo.eepisits.edu/1220/1/paper.pdf, 18 Januari 2015.

[3] Anhar, Panduan Menguasai PHP \& MySQL Secara Otodidak, Mediakita, Jakarta, 2010.

[4] Aziz, M., \& Pujiono, S., Sistem Informasi Geografis Berbasis Desktop dan Web, Penerbit Gava Media, Yogyakarta, 2006.

[5] Demers, M. N., Fundamentals of Geographic Information Systems, John Wileys \& Sons, Inc., New York, 1997.

[6] Dewanto, I. J., WEB DESAIN (Metode Aplikasi dan Implementasi), Graha Ilmu, Yogyakarta, 2006.

[7] Kadir, A., Pemrograman Web Mencakup: HTML, CSS, Javascript, \& PHP, Penerbit Andi, Yogyakarta, 2003.

[8] Kemenag Kabupaten Cilacap, EMIS 13-14 CILACAP, Kementerian Agama Kabupaten Cilacap, Cilacap, 2014.

[9] Nugroho, B., PHP dan MySQL dengan Editor Dreamweaver MX, Penerbit Andi, Yogyakarta, 2004.

[10] Prahasta, E., Sistem Informasi Geografis: KonsepKonsep Dasar (Perspektif Geodesi \& Geomatika), Informatika, Bandung, 2009.

[11] Pressman, R. S., Rekayasa Perangkat Lunak: Pendekatan Praktisi (Buku 1), Penerbit Andi, Yogyakarta, 2002.

[12] Purvis, M., Sambells, J., \& Turner, C., Beginning Google Maps Applications with PHP and Ajax: From Novice to Professional, Apress, Berkeley, 2006.

[13] Republik Indonesia, Salinan Undang-undang RI Nomor 20 Tahun 2003 tentang Sistem Pendidikan Nasional, http://www.kemenag.go.id/file/dokumen/UU2003.p df, 10 Desember 2014.

[14] Sommerville, I., Software Engineering (Rekayasa Perangkat Lunak) Jilid 1, Erlangga, Jakarta, 2003.

[15] Wahana, K., Panduan Praktis Menguasai Pemrograman Web dengan Javascript. Penerbit Andi, Yogyakarta, 2010. 